\title{
MEMPRODUKSI TEKS PROSEDUR KOMPLEKS MENGGUNAKAN MEDIA AUDIO VISUAL PADA SISWA SMA
}

\author{
Ai Marhayanti \\ Guru SMAN 4 Pontianak \\ Aimaraba201208@gmail.com
}

\begin{abstract}
The background of this research is about the low of study result because students's learning activity so low and the students' not familiar with scientific method. The focus of this reasearch is made procedure komplex text with audio-visual media. This media is a way how to increase the students' ability in producing complex procedure in a good text. The method used in this research is qualitative-descriptive method. The kind of this research is classroom action research which was conducted in three cycles. The subject of this research is SMA Negeri 4 Pontianak. The object research is the visualaudio media. The research instrument used is the test of study and also the observation sheet for observation the learning activity of the students and researcher. The results shows the medium of video could improve the writing skill complex procedure text, and the students' attitude havea good invroved.
\end{abstract}

\section{Keywords: Komplex Prosedure, Text, Visual Audio}

\section{PENDAHULUAN}

Menulis merupakan satu dari empat keterampilan berbahasa yang harus diajarkan kepada siswa mulai dari SD sampai dengan perguruan tinggi. Bagi seseorang yang terampil menulis, sangat bermanfaat untuk mengembangkan dan menata informasi. Dikatakan demikian karena menulis merupakan suatu kegiatan produktif dan ekspresif.

Kegiatan menulis yang produktif satu diantaranya adalah menulis menghasilkan teks prosedur kompleks.Memproduksi teks prosedur kompleks adalah satu diantara kompetensi yang harus dicapai siswa kelas X pada semester II (genap) pada kurikulum 2013. Siswa yang mahir memproduksi teks prosedur kompleks, dapat di pastikan bahwa siswa tersebut memunyai pola pikir yang teratur dan runtut. Oleh karena itu, melihat pentingnya

pembelajaran menulis teks prosedur kompleks ini, maka penulis tertarik untuk melakukan penelitian tentang memproduksi teks prosedur kompleks.

Penulis memilih SMA 4 Pontianak sebagai tempat penelitian karena dilandasi beberapa pertimbangan. Penulis adalah pengajar di SMAN 4 Pontianak, sehingga mempermudah proses penelitian. Selain itu, SMAN 4 Pontianak adalah satu dari 6 SMA Negeri di kota Pontianak yang merupakan pilot projeck atau sekolah contoh penerapan Kurikulum 2013 pada tahap I implementasi Kurikulum 2013.Selanjutnya, penelitian tentang teks prosedur kompleks belum pernah dilakukan di sekolah ini maupun di sekolah lainnya di kota Pontianak. 
Berdasarkan hasil penilaian pada pembelajaran memproduksi teks prosedur kompleks dari dua kelas $\mathrm{X}$ MIA yang penulis bimbing, siswa kelas $\mathrm{X}$ MIA 4 memiliki tingkat ketidaktuntasan kriteria ketuntasan minimal (KKM) (75/2.66) tertinggi dibandingkan dengan dua kelas $\mathrm{X}$ MIA lainnya. Siswa kelas X MIA 4 berjumlah 38 orang yang terdiri dari 24 orang siswi dan 14 orang siswa. Dari 38 orang siswa/siswi 30 orang tidak memenuhi KKM. Rendahnya pencapaian nilai siswa ini dilatarbelakangi oleh beberapa faktor antara lain:

1. Aktivitas belajar siswa masih sangat rendah.

2. Siswa belum terbiasa belajar dengan pendekatan Scientific.

3. Dalam beberapa kali praktik pembelajaran di kelas X MIA 4 peneliti lebih banyak aktif dari pada siswa. Kelas cenderung pasif, informasi lebih dominan dari guru kepada siswa.

$$
\text { Masalah dalam }
$$

penelitian ini adalah siswa SMA kelas X Mia 4 Sebagian besar siswa belum mampu mengembangkan idenya dalam tulisan dengan baik. Ketika memproduksi teks prosedur kompleks, dominan teks yang dihasilkan mmereka tidak sesuai dengan struktur teks prosedur kompleks yang terdiri atas tujuan dan langkah-langkah. Selain itu, respon yang ditunjukkan siswa ketika pembelajaran berlangsung juga kurang baik. Kelas cenderung pasif, informasi dominan dari guru kepada siswa bukan sebaliknya, atau tidak sesuai dengan konsep belajar yang diharapkan oleh kurikulum 2013.
Menurut Tarigan (1993:21) Menulis adalah menurunkan atau melukiskan lambang-lambang grafik yang menggambarkan suatu bahasa yang dipahami seseorang, sehingga orang lain dapat membaca lambanglambang garafik tersebut. Menulis pada dasarnya adalah proses untuk mengemukakan ide dan gagasan dalam bahasa tulis. Oleh sebab itu, Akhadiah (1988:2) memandang menulis adalah sebuah proses, yaitu proses penuangan gagasan atau ide kedalam bahasa tulis yang dalam praktiknya proses menulis diwujudkan dalam beberapa tahapan yang merupakan suatu sistem yang utuh.

Menulis juga dapat diartikan sebagai suatu kegiatan yang produktif dan ekspresif, dimana seorang penulis haruslah terampil memanfaatkan grafologi, struktur bahasa dan kosakata (Tarigan, 1993:4). Selanjutnya Lado (dalam Ahmadi 1990:28) mendefinisikan bahwa menulis adalah meletakkan atau mengatur, simbol-simbol grafis yang menyatakan pemahaman suatu bahasa sedemikian rupa hingga orang lain dapat membaca simbolsimbol grafis itu sebagai bagian penyajian ekspresi bahasa.

Dari beberapa definisi di atas menulis dapat didefinisikan melalui berbagai sudut pandang. Dalam sudut pandang yang paling sederhana, menulis dapat diartikan sebagai proses menghasilkan lambang bunyi. Dari sudut pandang yang lebih kompleks menulis dapat didefinisikan sebagai sebuah proses berkomunikasi secara tidak langsung antara penulis dengan pembacanya melalui penggabungan lambanglambang bunyi bahasa sehingga 
maksud dan tujuannya dapat dipahami.

Menulis merupakan pernyataan pikiran, gagasan, dan perasaan dalam bentuk tulisan yang diharapkan dapat dipahami oleh pembaca dan berfungsi sebagai alat komunikasi tidak langsung. Menulis juga dapat diartikan sebagai suatu kegiatan penyampaian pesan dengan menggunakan bahasa tulis sebagai alat medianya. Dalam hal ini, pesan mempunyai arti isi atau muatan yang terkandung dalam suatu tulisan, sedangkan tulisan merupakan suatu lambang atau simbol-simbol bahasa yang dapat dilihat dan disepakati pemakainya. Menulis pada dasarnya bukan hanya sekadar menuangkan isi pikiran ke dalam bentuk tulisan, tetapi lebih pada proses kreatif dalam menuangkan gagasan ke dalam wacana agar dapat dibaca, dan dipahami dengan mudah.

Menurut Akhadiah (1988:3), kegiatan menulis ialah suatu proses, yaitu proses penulisan. Artinya menulis dilakukan dalam beberapa tahap yaitu:

a. Tahap prapenulisan.

Dalam tahap ini ditentukan hal-hal pokok yang akan mengarahkan penulis dalam seluruh kegiatan penulisan itu.

b. Tahap penulisan

Dalam tahap penulisan dilakukan apa yang telah ditentukan, yaitu mengembangkan gagasan dalam kalimat-kalimat, satuan paragraf, bab, atau bagian, sehingga selesailah seluruh draf yang direncanakan.

c. Tahap revisi.

Dalam tahap ini yang dilakukan ialah membaca dan menilai kembali apa yang telah ditulis, memperbaiki, mengubah, bahkan jika perlu memperluas tulisan yang telah dihasilkan.

Pembelajaran menulis pada hakikatnya adalah suatu pembelajaran tentang bagaimana seseorang mengekspresikan ide dan perasaan lewat media tulisan. Melalui kegiatan menulis, seseorang juga bisa mengenali kemampuan dan potensi diri. Mampu mengemukakan gagasan dan melatih bernalar dalam menghubungkan fakta, mampu merekam pikiran-pikirannya mengenai hal-hal penting atau kegiatan-kegiatan dalam kehidupan, bahkan menulis dapat melatih berpikir serta berbahasa secara tertib, Akhadiah (1988:1)

Tarigan (1993:9) menyatakan bahwa tujuan pengajaran menulis adalah: (1). Membantu siswa memahami bagaimana berekspresi dapat melayani mereka melalui karya dan kegiatan menulis. (2) Meransang imajinasi dan daya pikir atau intelek siswa mengekspresikan diri secara bebas. (3) Siswa mampu menggunakan perangkat kaidah menulis dan menggunakan kaidah kebahasaan sewaktu menulis.

Pembelajaran menulis yang dilaksanakan para guru di sekolah minimal mempunyai tiga tujuan. Ketiga tujuan ini merupakan tujuan yang harus dicapai para siswa melalui pembelajaran menulis. Tujuan pertama pembelajaran menulis adalah menumbuhkan kecintaan menulis pada diri siswa. Tujuan ini menjadi sangat penting sebab mencintai menulis adalah modal awal bagi siswa agar mau menulis sehingga ia akan menjadi seorang yang terbiasa menulis. Semakin sering orang menulis akan semakin baik pula hasil tulisannya. 
Kemampuan siswa menulis merupakan tujuan pembelajaran yang kedua. Kemampuan menulis yang dimaksud adalah kemampuan siswa memproduksi berbagai ragam tulisan untuk berbagai kepentingan, sasaran, dan konteks sosial budaya. Berdasarkan tujuan ini, pembelajaran menulis harus diarahkan agar mampu membekali siswa berbagai strategi menulis, macam-macam tulisan, serta sarana publikasi tulisan.

Tujuan terakhir adalah agar siswa mampu menulis secara kreatif. Tujuan ini menghendaki agar siswa mampu menjadikan menulis bukan sekadar sebagai kompetensi yang harus dikuasai selama mengikuti pembelajaran, melainkan agar siswa mampu memanfaatkan menulis sebagai sebuah aktivitas yang mendatangkan berbagai keuntungan, baik keuntungan yang berbagai keuntungan, baik keuntungan yang bersifat psikologis, ekonomis, maupun sosiologis. Berkaitan dengan hal ini, menulis seyogyanya menjadi sebuah kebutuhan bagi siswa dalam rangka mengekspresikan sehingga terbebas dari beban psikologis. Jika siswa telah mencapai taraf ini, menulis bukanlah hal yang menakukatkan melainkan hal yang harus dilakukan agar ia merasa tenang dan termotivasi dalam hidup.

Keterampilan menulis adalah keterampilan proses. Mengajarkan keterampilan menulis seyogyanya lebih ditekankan pada proses menghasilkan satu tulisan, lebih pada bagaimana siswa secara bertahap mampu membuat karya tulis, tulisan tentang apa pun yang mereka tahu dan mereka sukai.
Menurut kamus besar bahasa Indonesia prosedur adalah langkahlangkah untuk menyelesaikan suatu masalah atau aktivitas, sedangkan kompleks adalah beberapa unsur yang pelik, rumit, sulit, dan saling berhubungan. Menurut Tika Atikah (2012:91) Teks prosedur kompleks adalah sebuah teks yang berisi langkah-langkah untuk meyelesaikan suatu masalah yang kompleks atau rumit, namun saling berhubungan.

Dalam setiap teks prosedur kompleks terdapat struktur teks yang terdiri dari:

1. Tujuan

Tujuan adalah hasil akhir yang ingin dicapai.

2. Langkah-langkah.

Langkah-langkah adalah cara yang ditempuh agar tujuan itu tercapai. Dalam teks prosedur kompleks langkah-langkah merupakan urutan yang tidak dapat dibolak balik. Dengan kata lain, langkah awal menentukan langkah berikutnya.

Bahasa yang digunakan dalam teks prosedur kompleks adalah bahasa yang jelas dan mudah di pahami. Adapun fitur bahasa teks Prosedur Kompleks menurut Maryanto, dkk (2014:40) sebagai berikut.

1. Partisipan manusia secara umum. Partisipan manusia adalah semua manusia yang terlibat atau berpartisipasi dalam dalam teks yang ditandai dengan kata ganti orang maupun penamaan.

2. Verba material

Verba material adalah verba yang mengacu pada tindakan fisik secara nyata.

3. Verba tingkah laku.

Verba tingkah laku adalah verba yang mengacu pada sikap yang 
dinyatakan dengan ungkapan verbal.

4. Konjungsi temporal.

Konjungsi temporal adalah konjungsi yang mengacu pada urutan waktu dan sekaligus sebagai sarana kohesi teks.

5. Kalimat imperatif, deklaratif dan interogatif.

Kalimat imperatif atau kalimat perintah adalah kalimat yang berfungsi untuk meminta atau melarang seseorang untuk melakukan sesuatu. Kalimat deklratif adalah kalimat yang berisi pernyataan, dan kalimat interogatif adalah kalimat yang berisi pertanyaan.

Untuk menghasilkan teks prosedur kompleks yang benar, yang bisa dilakukan adalah menerapkan semua kaidah yang menjadi ciri teks prosedur kompleks. Untuk itu, usahakan teks yang dibuat mengandung struktur teks yang baik, penggunaan bahasa Indonesia baku dan unsur-unsur kebahasaan yang mendukung langkah-langkah yang harus ditempuh.

Kata media berasal dari bahasa latin medius dan bentuk jamak dari kata medium yang secara harfiah berarti "tengah", "perantara" atau "pengantar". Soeparno (1988:1) mengatakan media adalah suatu alat yang dipakai sebagai saluran (Chanel) untuk menyampaikan suatu pesan (message) atau informasi dari sumber (resource) kepada penerimanya (receiver).

Menurut Sadiman dkk, (2008:10) media tidak hanya dipandang sebagai alat bantu, tapi lebih sebagai penyalur pesan dari pemberi pesan (guru) ke penerima pesan (siswa/pelajar), artinya media dapat menjadi wakil guru sebagai penyampai informasi secara lebih teliti, jelas dan menarik, dan dapat difungsikan walau tanpa kehadiran guru.

Gerlach dan Ely (dalam Arsyad, 2013: 3) mengatakan bahwa media apabila dipahami secara garis besar adalah manusia, materi, atau kejadian yang membangun kondisi yang membuat siswa mampu memperoleh pengetahuan, keterampilan atau sikap.

Mulyani Sumantri (dalam Rohman 2013:156) menyatakan media adalah segala alat fisik yang dapat menyajikan pesan serta peransang peserta didik untuk belajar seperti buku, film, kaset, disebut media.

Dengan demikian dapat diartikan bahwa media adalah alat bantu proses belajar mengajar atau segala sesuatu yang dapat dipergunakan untuk merangsang pikiran, perasaan, perhatian dan kemampuan atau ketrampilan pebelajar sehingga dapat mendorong terjadinya proses belajar yang efektif.

Media sebagai sumber belajar berkembang sesuai dengan perkembangan teknologi pembelajaran, baik berbentuk audio maupun visual, bahkan audio visual. Kehadiran media dalam pembelajaran berperan penting, karena media dapat menjadi pengantar untuk memperjelas materi, bahkan media dapat menyederhanakan sesuatu yang kompleks.

Hamalik (dalam Arsyad 2013:19) mengemukakan bahwa pemakaian media pembelajaran dalam pembelajaran dapat membangkitkan keinginan dan minat baru, 
membangkitkan motivasi, ransangan kegiatan belajar, dan bahkan membawa pengaruh psikologis pada siswa. Penggunaan media juga dapat membantu pemahaman, mempermudah penafsiran.

Media pembelajaran yang digunakan untuk membantu guru dalam menyampaikan materi pelajaran kepada siswa dalam pembelajaran, sehingga memudahkan pencapaian tujuan pembelajaran. Media juga sebagai bagian yang integrasi dengan rancangan pembelajaran yang harus dikuasai guru. Media juga dapat mengkonkretkan yang abstrak menjadi konkret. Hal ini memberikan peluang kepada para pendidik mengaplikasikan berbagai teknik pengajaran, sehingga peserta didik diberi kesempatan untuk memegang kekuasaan kontrol pada sebuah sesi pembelajaran. Peserta didik berpeluang menentukan teknik belajar sesuai karakteristiknya, guna membentuk pengetahuan berdasarkan kebutuhan , sehingga menumbuhkan motivasi, aktivitas, dan kreativitas.

Media pembelajaran audio-visual adalah alat bantu yang digunakan dalam kegiatan belajar-mengajar. Menurut Soeparno (1988:51) media pandang-dengar (audiovisual) adalah perpaduan antara dua media yaitu media pandang dan media dengar. Media pembelajaran audio-visual menggunakan alat berupa televisi, audio, film, program slide-tape. Media ini menfokuskan pada kecermatan penglihatan dan pendengaran siswa dalam menggunakan alat bantu media audiovisual. Ditinjau dari segi teknis, yang dimaksud dengan media pembelajaran audiovisual menunjukkan pada beberapa macam perangkat keras yang dipakai untukmenyampaikan ide dan pengalaman melalui mata dan telinga.

a) Slide

Menurut Arsyad (2013:48), "slide (film bingkai) adalah suatu film transparansi yang berukuran 35 $\mathrm{mm}$ dengan bingkai $2 \times 2$ inci”. Bingkai rsebut terbuat dari kartun dan plastik. Film bingkai diproyeksikan dengan suara yang dikenal dengan film bingkai bersuara atau slide bersuara. Media ini merupakan perpaduan antara dua media yaitu media pandang berupa slide dan media dengar berupa rekaman. Kedua media tersebut dipresentasikan bersama-sama untuk mengomunikasikan satu program. Prinsipkerjanya berupa memproyeksikan slide yang sudah diurutkan sedemikian rupa sehingga dapat menggambarkan urutan kejadian, yang kemunculannya dilakukan satu persatu disertainarasi hasil pemutaran pita rekaman.

b) Film

Menurut Arsyad (2013:50), "film atau gambar hidup merupakan gambar-gambar dalam frame, dimana frame demi frame diproyeksikan melalui lensa proyektor secara mekanis sehingga pada layar terlihat gambar itu hidup". Film bergerak dengan cepat dan bergantian sehingga memberikan visual yang kontiniu.

c) Video

Menurut Munir (2012:18) video pada dasarnya adalah alat atau media yang dapat menunjukkan simulasi benda nyata. Video juga dapat 
diartikan sebagai media digital yang menunjukkan susunan atau urutan gambar-gambar bergerak dan dapat memberikan ilustrasi/fantasi. Video juga dpat digunakan sebagai sarana untuk menyampaikan informasi yang menarik, langsung dan efektif.

$$
\text { d) Televisi }
$$

Televisi adalah sistem elektronik yang mengirimkan gambar diam dan gambar hidup bersama suara melalui kabel atau ruang, (Arsyad:2013:51). Sistem ini menggunakan peralatan yang mengubah cahaya dan suara kedalam gelombang elektrik dan mengonversikannya kembali kedalam cahaya yang dapat dilihat dan dapat di dengar.

Media ini merangkum karakteristik yang dimiliki oleh film dan radio. Saluran informasi yang sama dengan film, yakni lambang verbal, visual dan gerak, tetapi persentasinya sama dengan radio yaitu dengan cara mempersentasikan lewat pesawat pemancar yang kemudian diterima oleh si penerima informasi lewat pesawat penerima. Hubungan media audio dengan pengembangan keterampilan yang berkaitan dengan aspek-aspek keterampilan mendengarkan.

(a) Kelebihan dan Kelemahan Media Pembelajaran Audio-Visual. Menurut Arsyad (2011:49), kelebihan dan kelemahan media pembelajaran audiovisual (televisi dan video) adalah sebagai berikut: (1) Kelebihan media pembelajaran audio-visual (televisi dan video). (a) Dapat melengkapi pengalaman pengalaman dari siswa ketika mereka membaca, berdiskusi, berpraktik dan lain-lain. (b) Dapat menggambarkan suatu proses cara yang dapat disajikan secara berulang-ulang jika dipandang perlu. (b) Dapat menanamkan sikap dari segi-segi efektifnya. (c) Mangandung nilainilai positif, dapat mengandung pemikiran dan pembahasan dalam kelompok siswa. (d) Dapat menyajikan peristiwa-peristiwa berbahaya bila dilihat secara langsung. (e) Dapat menunjukkan kepada kelompok besar atau kecil, kelompok heterogen maupun perorangan. (f) Dalam kecepatan normal memakan waktu satu minggu dapat ditampilkan satu setengah menit.

(a) Kelemahan

Media Pembelajaran Audio-Visual (Televisi dan Video) (a) Umumnya memerlukan biaya dan waktu yang banyak. (b) Pada saat film dipertunjukkan, gambargambar bergerak terus sehingga tidak semua siswa mampu mengikuti informasi yang ingin disampaikan. (c) Film yang tersedia tidak terlalu sesuai dengan kebutuhan dan tujuan belajar diinginkan kecuali film atau video yang dirancang dan diproduksi untuk kebutuhan sendiri.

\section{METODE}

Penelitian ini dilaksanakan di kelas X MIA 4, SMAN 4 Pontianak pada semester ke-2 tahun pelajaran 2014/2015 dengan jumlah siswa 37 orang, terdiri dari 24 orang siswi dan 13 orang siswa. Metode yang digunakan dalam penelitian ini adalah metode deskriptif. Menurut Nawawi (2012: 67) metode deskriptif dapat diartikan sebagai prosedur pemecahan masalah yang 
diselidiki dengan menggambarkan atau melukiskan subjek penelitian.

Penelitian ini merupakan penelitian tindakan (action research), karena penelitian dilakukan untuk memecahkan masalah pembelajaran di kelas. Penelitian tindakan kelas adalah suatu penelitian yang digunakan secara sistematis reflektif terhadap berbagai tindakan yang dilakukan oleh guru sekaligus sebagai peneliti.
Penelitian Tindakan Kelas yang digunakan dalam penelitian ini adalah model penelitian yang diperkenalkan oleh Kurt Lewin (dalam Paizaluddin dan Marlinda, 2012:29) bahwa dalam satu siklus terdiri dari empat langkah, yaitu: 1) perencanaan, 2) aksi, 3) observasi, dan 4) refleksi. Untuk lebih jelasnya siklus kegiatan dengan desain PTK model Kurt lewin, sebagai berikut:

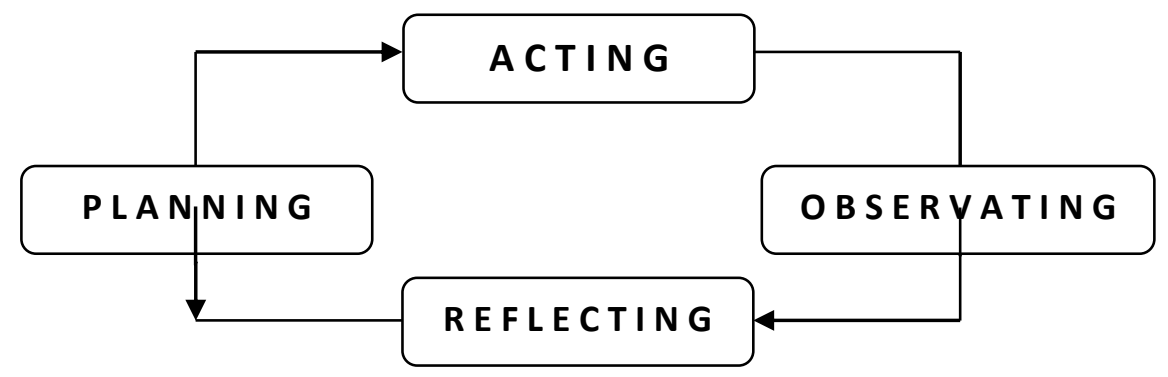

Gambar 1: Desain PTK Model Kurt Lewin

Data yang digunakan dalam penelitian ini ada dua macam yaitu data kualitatif yang meliputi seluruh aspek yang berkaitan dengan proses memproduksi teks prosedur kompleks pada siswa kelas X MIA 4 SMA Negeri 4 Pontianak tahun 2014/2015.

\section{HASIL DAN PEMBAHASAN}

Hasil

Pada tahap awal pembelajaran guru menggunakan model pembelajaran yang konvensional, siswa hanya diperintahkan untuk memproduksi teks prosedur kompleks dan kemudian mempretasikannya. Upaya yang dilakukan peneliti adalah mencoba menggunakan media video penggunaan media audio visual dalam peningkatan keterampilan

Data kedua adalah kuantitatif, yaitu data yang berkaitan peningkatan keterampilan memproduksi teks prosedur kompleks dengan menggunakan media audio visual pada siswa kelas X MIA 4 SMA Negeri 4 Pontianak tahun 2014/2015.

dalam meningkatkan keterampilan memproduksi teks prosedur kompleks. Penggunaan media video

pada siklus 1 ini dapat terlaksana dalam kegiatan pembelajaran. Penggunaan media video pada siklus 1 ini dapat terlaksana dalam kegiatan pembelajaran. Namun penggunaan 
media ini belum bisa digunakan secara maksimal. Pada siklus II aktivitas pembelajaran meningkat, guru dan siswa berusaha melaksanakan langkah pembelajaran dan aktivitas keterlibatan siswa sudah kelihatan. Peran guru sebagai fasilitator difungsikan dengan baik. Hasil pembelajaran semakin meningkat pada siklus III. Kegiaatan pelaksanaan pembelajaran pada siklus III memeperlihatkan adanya interaksi sehingga pembelajaran tampak hidup. Guru membuka diri untuk bertanya jawab dan siswa bersemangat untuk menjawab serta mengemukakan pertanyaan-pertanyaan . siswa juga telah memahami tujuan dari kegiatan pembelajaran.

\section{Pembahasan}

Perencanaan pembelajaran pada siklus I dimulai dari peneliti bersama kolabolator menyusun rencana pelaksanaan pembelajaran (RPP), menyiapkan media, menyusun panduan observasi dan alat penilaian. Siklus I ini terdiri dari beberapa bagian dengan uraian sebagai berikut: Tahap perencanaan dilaksanakan pada hari Sabtu tanggal 18 April 2015 adapun langkah-langkah pada tahap perencanaan ini adalah :

Membaca silabus yang berisikan kompetensi inti dan kompetensi dasar. 2) Membuat skenario pembelajaran memproduksi teks prosedur dengan menggunakan media video. 3) Pedoman penilaian teks hasil produksi teks prosedur kompleks 4) Pedoman observasi 5) Pedoman observasi kemampuan guru melaksanakan pembelajaran 6) Pedoman observasi sikap siswa yang terlampir dalam rencana pembelajaran. 7) Menentukan indikator kinerja. Pelaksanaa pembelajaran pada siklus I belum memenuhi kriteria sangat baik. Siklus II dimulai dengan membuat rencana pembelajaran berupa perangkat pembelajaran menggunakan media video yang berbeda dari siklus I. Selain itu, peneliti juga menyiapkan pedoman observasi yang akan digunakan peneliti dalam mengamati kegiatan pembelajaran yang dilakukan guru dan siswa menggunakan media video. Berdasarkan refleksi siklus II ditemukan proses belajar mengajar berjalan baik. Siklus II sudah mengambarkan peningkatan, langkah pembelajaran telah sesuai dengan rancangan, namun masih ditemukan ketidakpatuhan siswa pada waktu. rata-rata nilai 80,23 . Terdapat 30 orang siswa yang tuntas pada pembelajaran memproduksi teks prosedur kompleks dengan media video, dengan ketuntasan secara klasikal 78,94\%.

Table 1 Ketuntasan Klasikal dan Rata-Rata Kelas Memproduksi Teks Prosedur Komplek Siklus I

\begin{tabular}{llc}
\hline No & Kategori & persentase \\
\hline & Rata- rata kelas & $68,42 \%$ \\
\hline Ketuntasan klasikal; & $25 \%$ \\
\hline
\end{tabular}


ketidaktuntasan klasikal

$75 \%$.

Table 2 Ketuntasan Klasikal dan Rata-Rata Kelas Memproduksi Teks Prosedur Komplek Siklus II

\begin{tabular}{lll}
\hline No & Kategori & persentase \\
\hline & Rata- rata kelas & $78,94 \%$ \\
\hline Ketuntasan klasikal; & $80 \%$. \\
\hline & Ketidaktuntasan klasikal & $30 \%$
\end{tabular}

Siklus III dilaksanakan berdasarkan refleksi pada siklus II dengan hasil belum memuaskan. Perencanaan pembelajaran pada siklus III dirancang berdasarkan hasil refleksi siklus II. Berdasarkan refleksi siklus III kriteria ketuntasan minimal pada pada siklus III telah terlampaui dan penguasaan siswa terhadap pembelajaran menunjukkan peningkatan, demikian pula pada aktivitas dan sikap siswa pada pemelajaran. Rata-rata hasil memproduksi teks prosedur kompleks dengan media video pada siklus III adalah 92, $10 \%$ nilai ini sudah memenuhi standar ketuntasan minimal belajar yaitu 75 dan ketuntasan klasikal $85 \%$.

Table 3 Ketuntasan Klasikal dan Rata-Rata Kelas Memproduksi Teks Prosedur Komplek Siklus III

\begin{tabular}{lll}
\hline No & Kategori & persentase \\
\hline & Rata- rata kelas & $792,10 \%$ \\
\hline Ketuntasan klasikal; & $85 \%$. \\
\hline Ketidaktuntasan klasikal & $15 \%$ \\
\hline
\end{tabular}

\section{SIMPULAN DAN SARAN \\ Simpulan}

Berdasarkan penelitian dapat disimpulkan beberapa hal sebagai berikut: 1) perencanaan pembelajaran untuk meningkatkan keterampilan memproduksi teks prosedur kompleks menggunakan media video pada siswa X MIA 4 Pontianak tahun pembelajaran 2015/2016 SMAN 4 Pontianak siklus I,II,III direncanakan dua kali pertemuan. Pada siklus I masih mengalami kelemahan. Karena guru dan siswa masih belum mematuhi langkah-langkah

pembelajaran. Pada siklus II hasil pembelajaran semakin meningkat, guru dan siswa berusaha melaksanakan langkah pemebelajaran dan aktivitas pembelajaran sudah kelihatan. Hasil pembelajaran semakin meningkat pada siklus III. Kegiatan pelaksanaan pembelajaran memperlihatkan adanya interaksi 
antara guru dan siswa sehingga pembelajaran tampak hidup.

\section{Saran}

1) Sebaiknya pembelajaran keterampilan memproduksi teks prosedur kompleks diarahkan pada peningkatan keterampilan daripada pengetahuan atau penguasaan system dan tata cara memproduksiteks prosedur kompleks. 2) Pembelajaran keterampilan memproduksi teks prosedur kompleks di kelas X MIA 4 sebaiknya menggunakan media video

\section{DAFTAR RUJUKAN}

Ahmadi, Muhsin. 1990. Strategi Belajar MengajarKeterampilan Berbahasa dan Apresiasi Sastra. Malang: Yayasan Asih Asah Asuh Akhadiah, Sabarti dkk.1988. Pembinaan Kemampuan Menulis Bahasa Indonesia. Jakarta: Erlangga

Arsyad, Azhar. 2011. Media Pembelajaran. Jakarta: PT. Raja Grafindo Persada

Direktorat Pembinaan SMA. 2014. Pembelajaran Bahasa Indonesia Melalui Pendekatan Saintifik. Jakarta: Direktorat Jendral Pendidikan Menengah, Kementrian Pendidikan dan Kebudayaan.

Hatikah, Tikah dkk. 2013. Bahasa Indonesia. Jakarta: Grafindo

Kemendikbud. 2013. Kurikulum 2013 Kompetensi Dasar SMA/MA. Indonesia:Kemendikbud

Kemendikbud. 2013. Materi Pelatihan Guru Implimentasi Kurikulum 2013 SMA/MA dan SMK/MAK Bahasa Indonesia.Jakarta: Kemendikbud

Keraf, Gorys. 1981. Eksposisi dan Deskripsi. Ende-Flores: Nusa IndahYayasan Kanisius yang memberikan kemudahan bagi siswa untuk mengungkapkan informasi. 3) Pembelajaran memproduksi teks prosedur kompleks dapat dilakukan dengan menggunakan media video. Melalui media video memotivasi siswa untuk membuat keterkaitan antara pengetahuan dengan aplikasinya dalam kehidupan nyata.

Maryanto, dkk. 2013. Buku Guru Bahasa Indonesia Ekspresi Diri dan Akademik Kelas X. Jakarta: Kemendikbud

Maryanto, dkk. 2014. Buku Paket Bahasa Indonesia Ekspresi Diri dan Akademik Kelas X. Jakarta: Kemendikbud

Muchith, Saekhan. 2008. Pembelajaran Kontekstual.Semarang: Media Group

Munir. 2012. Multimedia; Konsep dan Aplikasi dalam Pendidikan. Bandung: Alfabeta

Moleong, Lexy. J. 2002. Metodologi Penelitian Kualitatif. Bandung: PT. Remaja Rosdakarya.

Nawawi, Hadari. 2012. Metode Penelitian Bidang Sosial. Yogyakarta: Gadjah Mada University Press

Nurgiyantoro, Burhan. 1988. Penilaian dalam Pengajaran Bahasa dan Sastra. Yogyakarta: BPFE Yogyakarta

Nurgiyantoro, Burhan. 2012. Penilaian Pembelajaran Bahasa Berbasis Kompetensi. Yogyakarta: BPFE. Yogyakarta. 
Paizaluddin, Ermalinda. 2012. Penelitian Tindakan Kelas (classroom action research) Panduan Teoritis dan Praktis. Bandung:Alfabeta

Purwanto, M. Ngalim. 1990. PrinsipPrinsip dan Evaluasi Pengajaran. Bandung: PT. Remaja Rosdakarya

Rohman, Muhammad dan Sofan Amri. 2013. Strategi \& Desain Pengembangan Sistem Pembelajaran. Jakarta: Prestasi Pustakaraya

Rusman. 2012. Belajar dan Pembelajaran Berbasis Komputer. Bandung. Alfabeta

Sadiman, Arief S dkk. 2008. Media pendidikan; Pengertian, Pengembangan, dan Pemanfaatannya. Jakarta: PT. Raja Grafindo Persada.

Soeparno. 1988. Media Pengajaran Bahasa. Yogyakarta: PT. Intan Pariwara.
Sudjana, Nana. 2009. Penilaian Hasil Proses Belajar mengajar. Bandung: remaja Rosdakarya

Susilana dan Cepi Riyana. 2007. Media Pembelajaran. Bandung: Wacana Prima

Tarigan, Henry Guntur. 1993. Menulis Sebagai Suatu Keterampilan Berbahasa. Bandung: Angkasa

Wiriaaatmaja, Rochiati. 2006. Metode Penelitian Tindakan Kelas. Bandung: PT. Remaja Rosdakarya 